\title{
赤外線放射による合成樹脂板の加熱過程の定量的検討
}

\author{
正員宮 永 俊之 (電力中研) \\ 正員 中 野 幸夫 (電力中研)
}

\section{Analysis of Infrared Radiation Heating of Plastics}

Toshiyuki Miyanaga, Member, Yukio Nakano, Member (Central Research Institute of Electric Power Industry)

In order to make more effective use of infrared radiation, we have developed a basic method for predicting the heating effect quantitatively.

It allows one dimensional heat transfer analysis taking account of spectral properties. We can estimate the distribution and temporal variations of temperature inside the plastic plates to be heated. This method is applicable to heating systems without vaporization and enables us to predict what kind of emitter is most suitable to the platsic plate to be heated.

キーワード：赤外線加熱, 分光吸収特性

\section{1. まえがき}

赤外線による加熱は被加熱物を直接かつ瞬時に熱す ることができる。また，赤外線のもつエネルギーが小 さいため，被加熱物を非熱的に変質させることなく加 熱でる。このため, 赤外線加熱は塗装乾燥, 食品加 工，医療など幅広い分野において効率が良く，付加価 檤の高い加熱方式として注目され，従来からその適用 技術の開発や適用分野の開拓が盛んに行われている。

郝線加熱のこのような特長を十分に発揮させるた めには，被加熱物の赤外線吸収特性を十分考慮し， そ れに応じた波長の赤外線を必要墨だけ照射する必要が あるがここのような加熱の過程を定量的に吟味するこ とは一般に行われていないようである。しかし，赤外 線加熱の効率をより高め，また被加熱物の加工価傎を より高めるには，被加熱物の表面や内部において赤外 線が吸収され，被加熱物の温度が上昇してゆく過程の 理諭的検討が非常に重要である。

赤外線加熱理論に関しては，西村らがソーダガラス に赤外線を照射した場合の加熱過程について検討した しの价どがあるがここでは合成樹脂の成形加工の ための予熱工程を想定して, 熱源として用いる赤外線 放射体の分光放射特性と，被加熱物である合成樹脂の
分光吸収特性から被加熱物の昇温特性を予測すること を試みた。「どの被加熱物にはどの赤外線放射体が最 適か?といったような判断を定量的に下せるように するためである。

本論文では，放射特性の異なる3 種類の赤外線放射 体(近赤外線をよく放射するランプ形放射体 1 種, 遠 赤外線をよく放射するパネル形放射体 2 種)からの赤 外線を 4 種類の合成樹脂板(アクリル，テフロン，塩 化ビニル，ポリエチレン)に垂直に照射した場合の加 熱過程について理論解析を行い, 実験結果と比較し た。この結果，合成樹脂板の表面および内部の昇温特 性を良い精度で予測でき，これによって，被加熱物に 適した赤外線放射体の選択が定量的に行えることなど が明らかになった。用いた解析手法は合成樹脂板に照 射された赤外線の吸収を波長ごとに考慮しており，蒸 発など物質の移動のない加熱過程に適用できる。

\section{2. 赤外線の放射および吸収特性を考慮した} 非定常一次元熱伝導解析

〈2・1〉理論解析式 図1に示すように，大気中 に水平に置いた厚さ $d$ 無限平板(被加熱物)圭想定 し，上部に設置した赤外線放射体から平板表面に垂直 に入射する放射熱流束を $Q_{0}\left(\mathrm{~W} / \mathrm{m}^{2}\right)$ とする。 


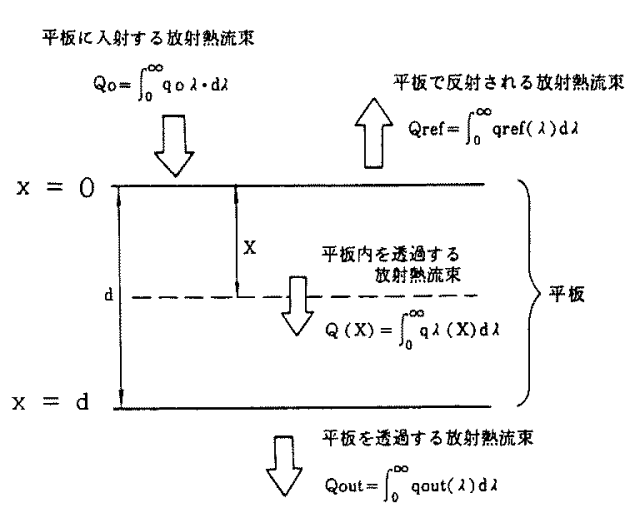

図 1 解析に用いた一次元モデル

Fig. 1. Model for analysis.

$$
\text { ここで, }
$$$$
Q_{0}=\int_{0}^{\infty} q_{0} \lambda \cdot d \lambda\left(\mathrm{W} / \mathrm{m}^{2}\right)
$$

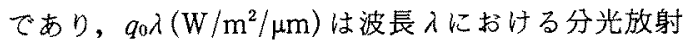
熱流束である。このモデルにおける熱伝導方程式を導 くにあたり，次のような仮定を置いた。

（1）被加熱物内での熱移動は伝導および放射によ るもののみとし，物質の移動を伴わないものとする。 また熱の移動柱垂直方向のみとする。

（2）入射波の散乱は吸収, 反射に比べ十分小さ く，無視できるものとする。

（3）熱的な物性值は温度によらない定数とする。 以上の仮定に基づき被加熱物内の一次元熱伝導方程式 を書くと

$$
C \rho \frac{\partial T(x, t)}{\partial t}=k \frac{\partial^{2} T(x, t)}{\partial x^{2}}-\frac{\partial Q(x)}{\partial x} . .
$$

となる。

ここで, $T(x, t):$ 平板内部の温度 $(\mathrm{K}), C:$ 平 板の比熱 $(\mathrm{J} / \mathrm{kg} / \mathrm{K}), \rho:$ 平板の比重 $\left(\mathrm{kg} / \mathrm{m}^{3}\right)$, $k:$ 平板の $x$ 方向の熱伝導率 $(\mathrm{W} / \mathrm{m} / \mathrm{K}), Q(x)$ : $x=x$ における平板に入射した赤外線の放射熱流 束 $\left(\mathrm{W} / \mathrm{m}^{2}\right), t:$ 時間 $(\mathrm{s})$

また，境界条件は以下のとおりである。

$t=0,0 \leqq x \leqq d$ において

$T(x, 0)=T a=$ const

$T a:$ 大気温度 $(\mathrm{K})$

$t>0, x=0, d$ に拈いて

$-k \frac{\left.\partial T\right|_{x=0, d}}{\partial x}=\left.H\right|_{x=0, d}+\left.R\right|_{x=0, d}\left(\mathrm{~W} / \mathrm{m}^{2}\right)$

$\left.H\right|_{x=0, d}=\left.h\right|_{x=0, d}\left(\left.T\right|_{x=0, d}-T a\right)\left(\mathrm{W} / \mathrm{m}^{2}\right)$

$$
\left.R\right|_{x=0, d}=\pi \int_{0}^{\infty}\left\{\varepsilon(\lambda) E b \lambda\left(\left.T\right|_{x=0, d}\right)\right\} d \lambda-\varepsilon^{\prime} \sigma T a^{4}
$$$$
\left(\mathrm{W} / \mathrm{m}^{2}\right)
$$

ここで, $H,\left.R\right|_{x=0, d}: x=0, d$ (平板表面, 襄面) における熱伝達量および平板表面を取り囲む半球 面空間との単位面積あたりの放射熱交換量

$\left.h\right|_{x=0, d}: x=0, d$ に扔ける熱伝達係数 $\left(\mathrm{W} / \mathrm{m}^{2} / \mathrm{K}\right)$ $\varepsilon(\lambda): x=0, d$ に扔引る平板表面の波長 $\lambda$ に扔け 了分光放射率

$E b \lambda(T)$ : 温度 $T$ における黑体の分光放射輝度 は次式で与えられる。

$$
\begin{aligned}
& E b \lambda\left(\left.T\right|_{x=0, d}\right)=\frac{2 C_{1}}{\lambda^{5}\left[\exp \left\{C_{2} /\left(\left.\lambda \cdot T\right|_{x=0, d}\right)\right\}-1\right]} \\
& \left(\mathrm{W} / \mathrm{m}^{2} / \mu \mathrm{m} / \mathrm{str}\right) \cdots \cdots \cdots(7)
\end{aligned}
$$

である。また，平板を取り囲む背景(温度 $T a$ ) は放射 率 $\varepsilon^{\prime}$ の灰色体として考えた。

〈2・2〉放射熱流束 平板内で反射や散乱がなく, 平板の厚さ方向に伝搬する赤外線では，その隇衰に関 して次式が成り立つ。

$$
I(\lambda, x)=I(\lambda, 0) \exp (-\alpha \lambda \cdot x) \quad\left(\mathrm{W} / \mathrm{m}^{2} / \mu \mathrm{m}\right)
$$

$I(\lambda, x): x=x$ での分光強度, $\alpha \lambda:$ 分光吸収係数

$$
(1 / \mathrm{m})
$$

平板に垂直に入射した赤外線は，図 2 に示すように内 部境界面において多重反射を繰返しながら強度が減衰 すると考えられる。従って, 赤外線放射による加熱効 果を定量的に評価するために，平板内部の放射熱流束 を図1に示すようにモデル化した。この図において，

$Q_{\mathrm{ret}}$ : 多重反射を繰返す過程で平板の表面側に反 射する放射熱流束，Qout：多重反射を繰返す過程 で平板の辌面側に透過する放射熱流束， $q_{\mathrm{rer}}(\lambda)$ : $Q_{\text {ref }}$ の分光成分, $q_{\text {out }}(\lambda): Q_{\text {out }}$ の分光成分, $q \lambda(x): Q(x)$ の分光成分である。

また，図 2 に示したように，平板境界面でのある波 長における真の分光反射率を $\chi(\lambda)$, 平板(厚さ $d$ の真 の分光透過率を $\tau(\lambda)\{=\exp (-\alpha \lambda \cdot d)\}$ とすると, 図 1 における $q_{\mathrm{ref}}(\lambda), q_{\text {out }}(\lambda), q \lambda(x)$ は

$$
\begin{aligned}
& q_{\text {ref }}(\lambda)=\left[x+\frac{x\{(1-x) \tau\}^{2}}{1-(x \cdot \tau)^{2}}\right] q_{0} \lambda \\
& q_{\text {out }}(\lambda)=\frac{(1-x)^{2} \tau}{1-(x \cdot \tau)^{2}} q_{0} \lambda \ldots \ldots \ldots .
\end{aligned}
$$




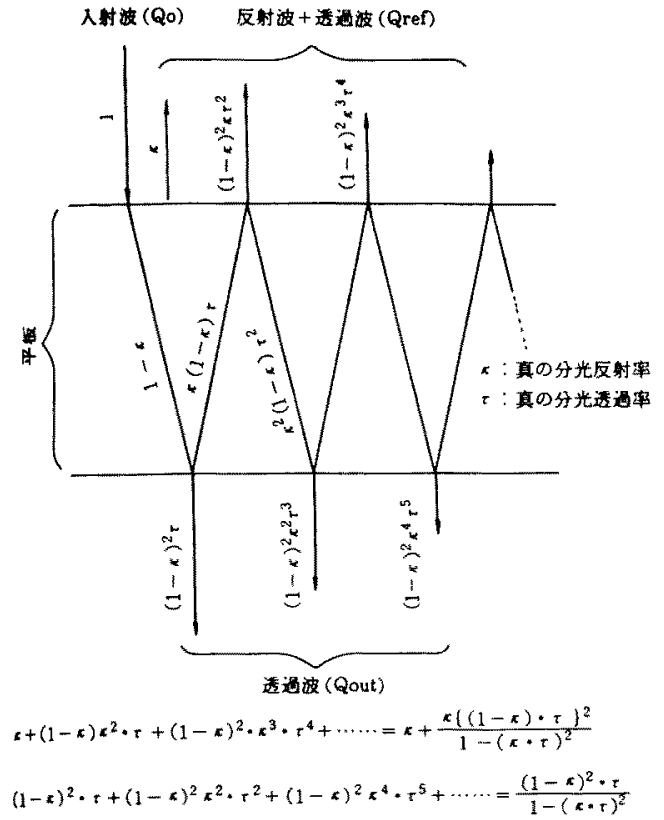

図 2 境界面における多重反射

Fig. 2. Multiple internal reflections at boundaries.

$$
q \lambda(x)=\frac{\exp \{-\alpha \lambda \cdot x\}+x \tau^{2} \exp \{\alpha \lambda \cdot x\}}{1-(x \cdot \tau)^{2}}
$$

となる。これらを波長全域で積分することによって

$$
\begin{aligned}
& Q_{\mathrm{ret}}=\int_{0}^{\infty} q_{\mathrm{ref}}(\lambda) d \lambda \\
& Q_{\text {out }}=\int_{0}^{\infty} q_{\text {out }}(\lambda) d \lambda \\
& Q(x)=\int_{0}^{\infty} q \lambda(x) d \lambda
\end{aligned}
$$

となる。また，分光光度計を用いて測定される平板の 分光透過率を $T(\lambda)$ ，分光反射率を $R(\lambda)$ とすると， 各々の定量式は

$$
\begin{aligned}
& T(\lambda)=\frac{q_{\text {out }}(\lambda)}{q_{0} \lambda}=\frac{(1-x)^{2} \tau}{1-(x \cdot \tau)^{2}} \ldots \ldots . . \\
& R(\lambda)=\frac{q_{\mathrm{rer}}(\lambda)}{q_{0} \lambda}=x+\frac{x\{(1-x) \tau\}^{2}}{1-(x \cdot \tau)^{2}}
\end{aligned}
$$

である。(15)，(16)式加ら，真の分光反射率 $x(\lambda)$ お よび分光透過率 $\tau(\lambda)$ が求まる。

〈2.3〉数値解析 (2)式を差分法を用いて解き, 平板断面各点の温度変化を計算した。

なお，(2)式の $Q(x)$ を求めるには波長積分を必要 とするがここれに関しては以下の上うに扱った。ま

\begin{tabular}{|c|c|c|c|}
\hline 淕料 & 比重 $\times 10$ ' $/ \mathrm{kg}$ m" & 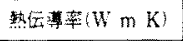 & 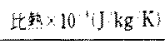 \\
\hline アクリル & 1.2 & 0.20 & 1.50 \\
\hline 塩化ピニル & 1.3 & 0.23 & 1.54 \\
\hline テプン & 2.4 & 0.26 & 1.04 \\
\hline ポり土チレン & 0.9 & 0.32 & 2.30 \\
\hline
\end{tabular}

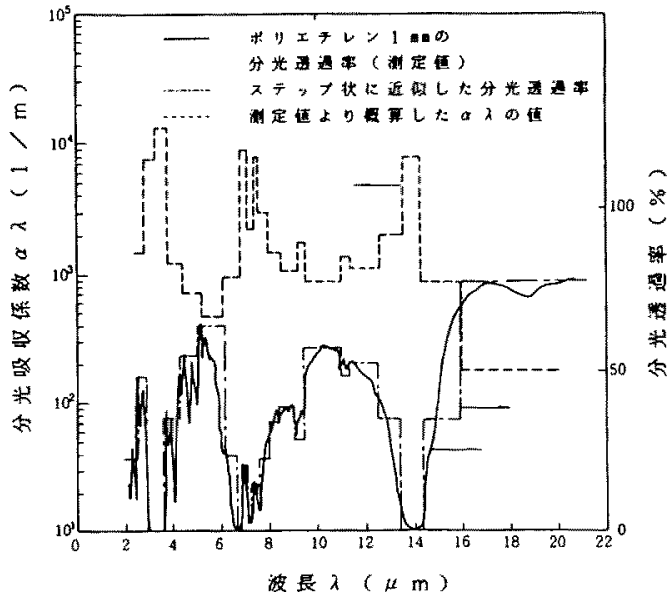

図 3 分光吸収保数の近似

Fig. 3. Approximation of spectral absorption coefficient.

表 1 被加熱物の熱的物性值

Table 1. Thermal properties of test pieces.

ず，放射体の分光放射率㧍上び平板の分光透過率，分 光反射粱をステップ状の関数で近似した。ポリエチレ ン板（厚さ $1 \mathrm{~mm}$ ) の分光透過率の例を図 3 の一点鎖線 で示す。こ机らから，図3の破線で例示するような分 光吸収倸数 $\alpha \lambda$ 求めた。こうして求めた分光吸収保 数から，波長区域ごとに平板が吸収する放射熱流束を 算出し，すべて加算することによって，(14)式の值を 求めた。この值を差分式に代入し, 平板断面各点の温 度の時間変化老，初期条件式 $(3) \sim(6)$ に従い計算し た。なお，数值解析に用いた合成樹脂板の熱的物性值 を表 1 に示す。これらのうち, 比重と熱伝導率は測定 值であり，比熱は文献(2)の值を採用した。また，合 成樹脂板の表面抢上び裏面に扔ける大気の熱伝達係数 は，文献( 3 ) 0自然対流熱伝達の式を用いて計算し, 大気温度が $300 \mathrm{~K}$ のをき, 合成樹脂板の表面で $6 \mathrm{~W}$ $/ \mathrm{m}^{2} / \mathrm{K}$, 哀面で $3 \mathrm{~W} / \mathrm{m}^{2} / \mathrm{K}$ とした。さらに（6)式の 合成樹脂板周囲の大気の放射率 $\varepsilon^{\prime}$ を 1.0 とした。赤 外線放射体加平板に放射さ机る放射熱流束は，次章 で述べる加熱実験と同じ $790 \mathrm{~W} / \mathrm{m}^{2}$ を用いた。 


\section{3. 実験装置および方法}

実験装置の概略を図 4 に示す。実験に使用した赤外 線ランプ 1 種 $(100 \mathrm{~V}, 375 \mathrm{~W}$, フィラメント温度約 $\left.2,400^{\circ} \mathrm{C}\right)$, 遠赤外線七一夕 2 種 $(\mathrm{A}, \mathrm{B}$, 各々表面温度 $\left.330^{\circ} \mathrm{C}\right)$ の分光放射輝度を図 5 に示す。な拉, 赤外線 ンプ $1.4 \mu \mathrm{m}$ 以下における分光放射輝度は文献(1) から引用した。放射体加ら平板に入射する放射熱流束 $Q_{0}$ が $790 \mathrm{~W} / \mathrm{m}^{2}$ になるように放射体と平板の距離を 調整した。

被加熱試料の平板として, 縦 $100 \mathrm{~mm}$, 横 $100 \mathrm{~mm}$, 厚さ $1 \mathrm{~mm} の$ 合成樹脂板 4 種(アクリル, 塩化ビニル, テフロン，ポリエチレン)を用いた。各合成樹脂板の 分光透過率, 分光反射率を図 6 , 図 7 に示す。これら の分光特性測定において, 波長 $2.5 \mu \mathrm{m}$ までは分散形 分光光度計を，それ以上の波長領域ではフーリエ変換 形分光光度計を用いた。

実験に際し, 赤外線ランプは定格入力電力で使用 し，遠赤外線ヒータはセラミック系の接着剤によって

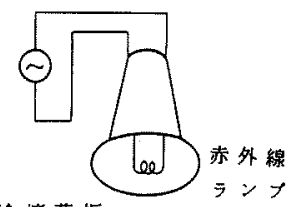

水冷造蔽板

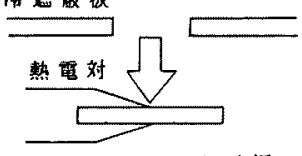

合成杫脂平板

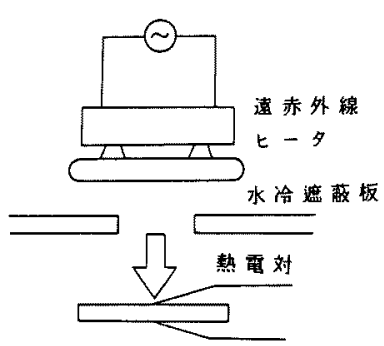

合成新脂平板
図 4 実験装置の概略

Fig. 4. Apparatus for infrared radiation heating test.

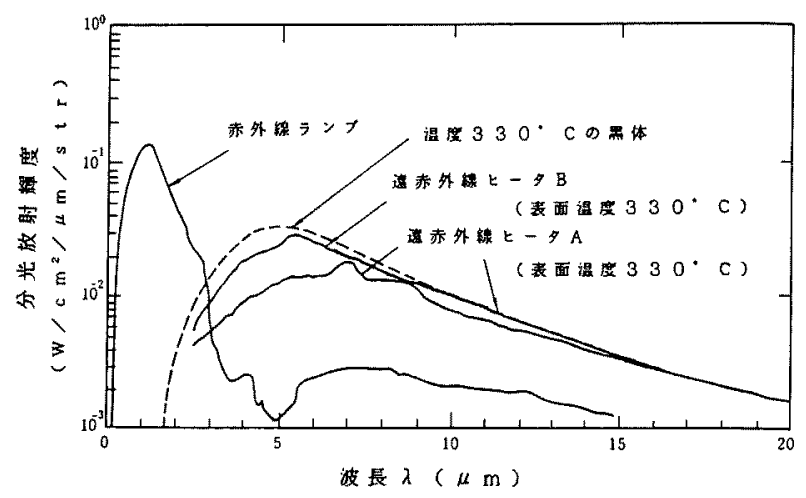

图 5 赤外線放射体の分光放射輝度

Fig. 5. Spectral radiation intensity.
熱電対を表面に取付け，表面温度を一定に保つように 入力電力を制御した。以上のような装置において，合 成樹脂板を加熱し，表面と襄面の温度の時間変化を剆 定した。

\section{4. 結果および検討}

〈4・1〉解析手法の妥当性の検証 加熱実験わよ び数值解析の結果の一例としてアクリル板, テフロン 板およびポリエチレン板(各々厚さ $1 \mathrm{~mm}$ )の表面と裏 面の昇温特性を図 8 , 図 9, 図 10 に示す。赤外線放 射体と加熱される合成樹脂板の組合せによっては，解

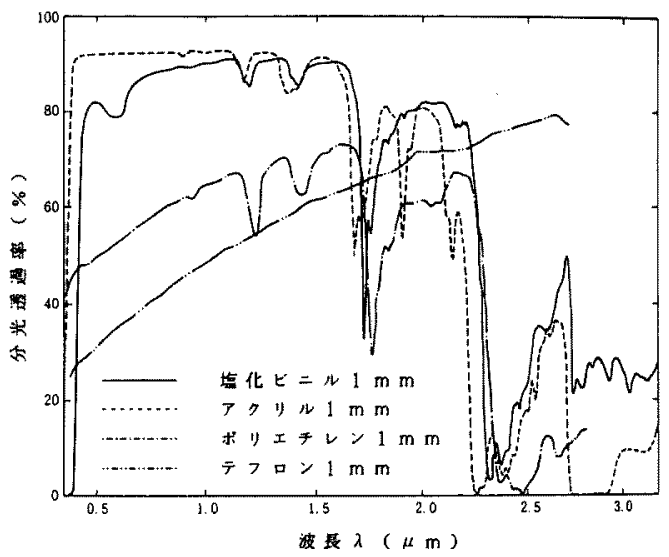

(a) $0 \mu \mathrm{m}<\lambda(\mu \mathrm{m})<3.2 \mu \mathrm{m}$

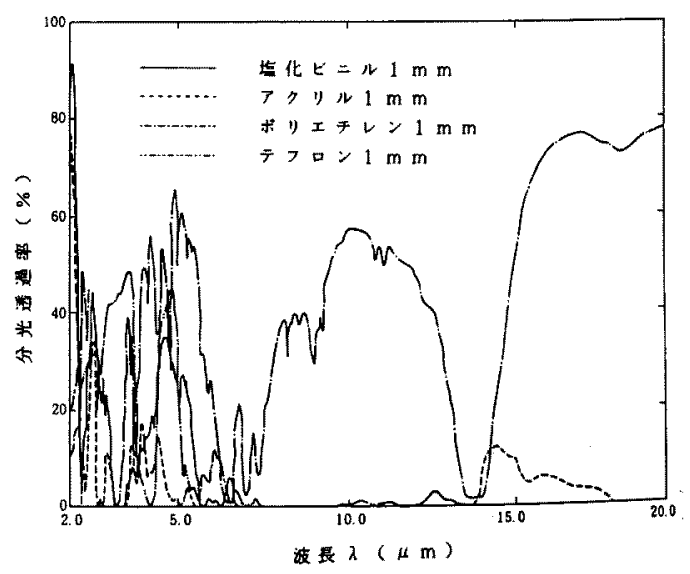

(b) $2.5 \mu \mathrm{m}<\lambda(\mu \mathrm{m})<20.0 \mu \mathrm{m}$

図 6 合成樹脂板の分光透過率

Fig. 6. Spectral transmittance of test pieces. 


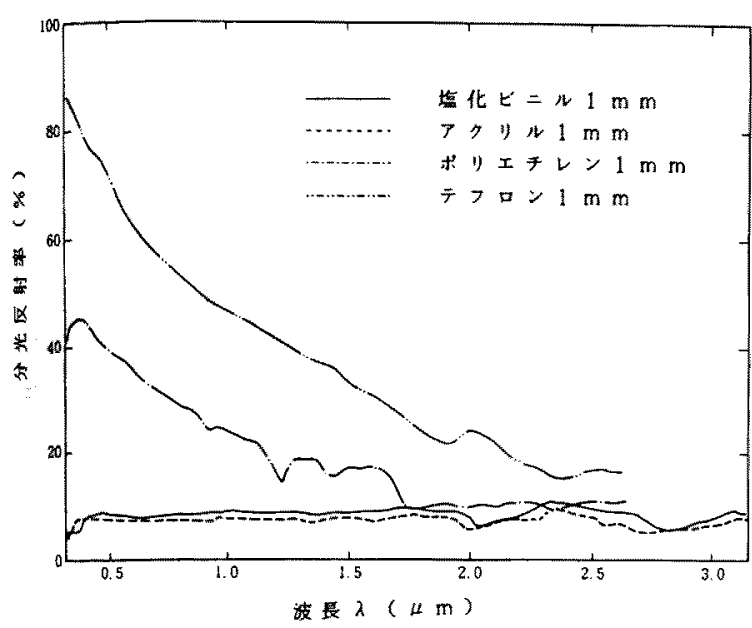

(a) $0 \mu \mathrm{m}<\lambda(\mu \mathrm{m})<3.2 \mu \mathrm{m}$

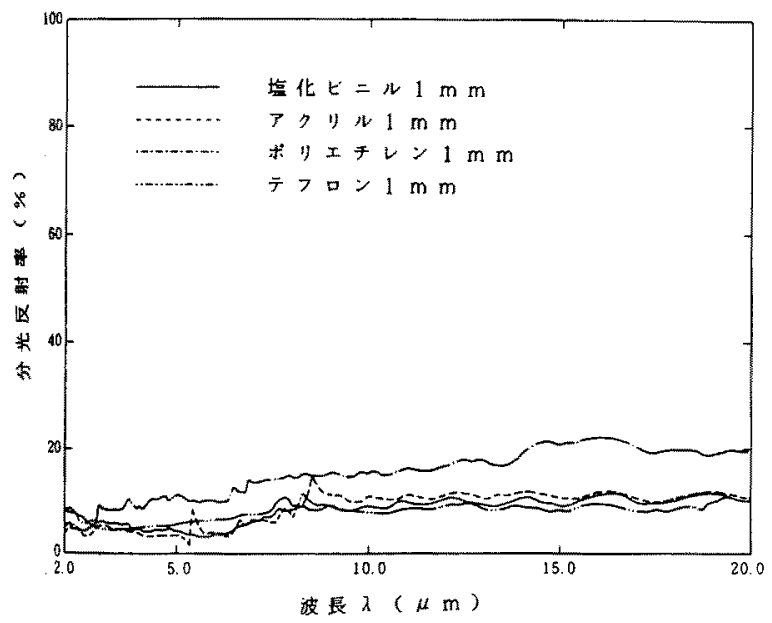

(b) $2.5 \mu \mathrm{m}<\lambda(\mu \mathrm{m})<20.0 \mu \mathrm{m}$

図 7 合成樹脂板の分光反射率

Fig. 7. Spcetral reflectivity of test pieces.

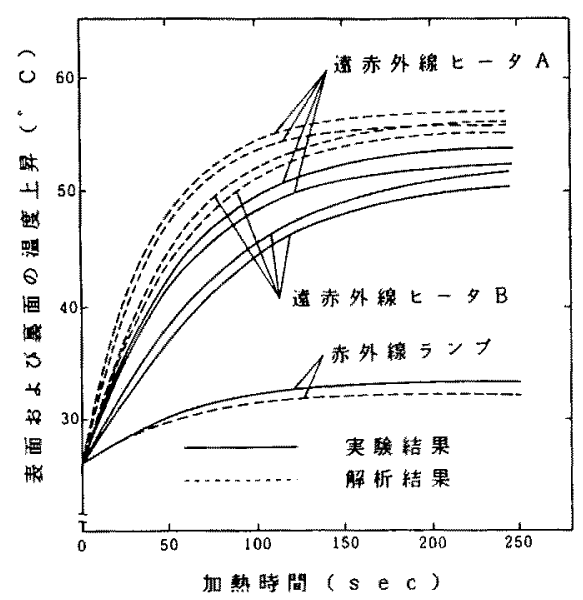

図 8 アクリル板(厚さ $1 \mathrm{~mm}$ ) の昇温特性

Fig. 8. Temporal variations of tempera. ture.

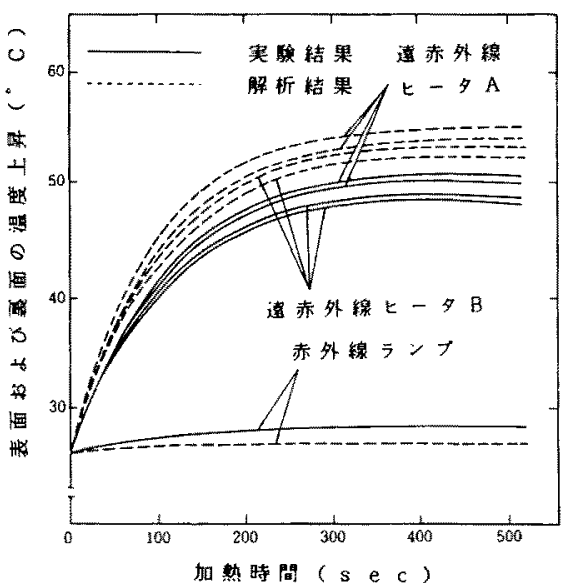

図 9 テフロン板(厚さ $1 \mathrm{~mm}$ )の显温特性

Fig. 9. Temporal variations of temperature.
析結果と実験結果にやや大きな差異が生じているが, 解析結果溒赤外線七一夕 A，Bに対古る各合成樹 脂板の昇温特性の傾向の荎異(アクリル，テフロンに ついては遠赤外線七一タAのはうが遠赤外線ヒー夕 Bより加熱結果が大きく，逆にポリエチレン板につい ては遠赤外線ヒータ B のほうが大さいこと)ゃ, 赤外 線ランプの加熱効果が遠赤外線ヒータより著しく劣る ことを明確に示している。

図80遠赤外線七一夕A，Bの解析結果は実験結 果に对し昇温過程で 14\%程度の差翼を生じているが, 平衡温度 (合成樹脂板が最終的に到達する温度)および 平衡温度に達するまでの所要時間に関する差翼は $5 \%$
以下であった。また，図9、図10では昇温過程につ いても平衡温度ちよび平衡温度に達する所要時間につ いても解析結果と実駼結果の差異は $10 \%$ 以下であっ た。このことから解析結果と実験結果は比較的良い一 致を示しているといえる。

解析結果と実験結果の異の原因として，合成教脂 板の分光透過率をステップ状に近似していることに伴 う誤差の蓄積跲成樹脂板の比熱を文献より引用し, 一つの值で代表させていることなどが兴げられる。

今後，更に詳細な近似や正確な蠜的物性値の把握に より予測精度の向上が期待される。 


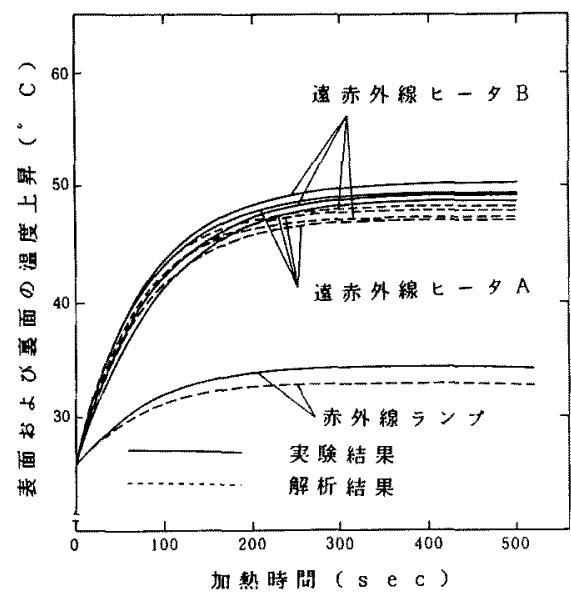

図10 ポリエチレン板(厚さ $1 \mathrm{~mm}$ )の昇温 特性

Fig. 10. Temporal variations of temperature.

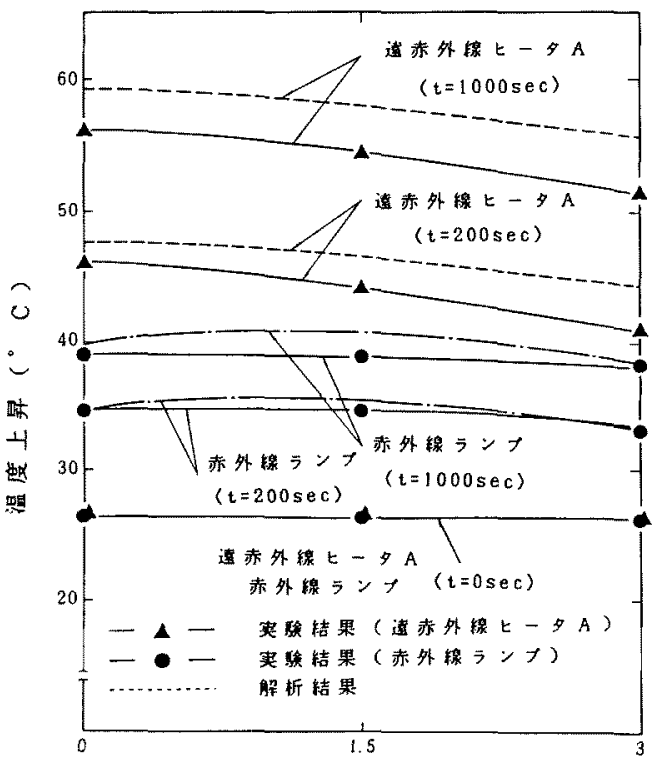

被加熱物の表面加らの深さ $(\mathrm{mm})$

図 11 アクリル板(厚さ $3 \mathrm{~mm}$ )内部の 温度分布

Fig. 11. Distribution of temperature in the test piece.

また, 厚さ $3 \mathrm{~mm}$ のアクリル平板を対象に合成樹脂 板内部の温度分布について解析と実験を行った。な 扔, 実験では合成樹脂板の側面に直径 $0.6 \mathrm{~mm}$ のドリ ルで究をあけ, 直径 $0.1 \mathrm{~mm} の K$ 熱電対を插入し,

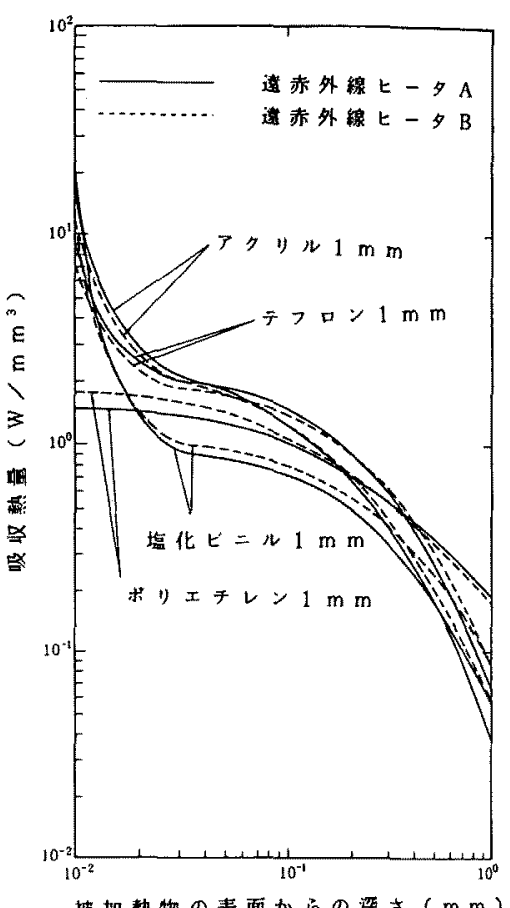

被扣熱物の表面からの溧さ $(\mathrm{mm})$

図 12 合成樹脂板内部の吸収熱量分布 (遠赤外線七一夕)

Fig. 12. Distribution of absorbed radiation heat flux by long infrared emitter A, B.

シリコングリスを注入し，熱電対を固定した。加熱開 始加ら 0 秒, 200 秒, 1,000 秒後の合成樹脂板内部の 温度分布についての実験と解析の結果を図 11 に示す。 両者はほぼ致した。

以上から本解析手法の妥当性が検証された。

〈4・2〉 合成樹脂板内部での吸収熱量分布 放射 熱流束が合成樹脂板内部のある場所でどの程度吸収さ れるかを知るために，吸収熱量分布一 $\partial Q(x) / \partial x$ を計 算した。計算結果を図 12 (遠赤外線ヒー夕 $\mathrm{A}, \mathrm{B} て ゙$ 加 熱した場合) および図 13(赤外線ランプで加熱した場 合)に示す。図の横軸は合成樹脂板表面からの深さて ある。

図12 から，アクリル，テフロンおよび塩化ビニル では放射熱流の大部分が表面付近で吸収され表面加熱 に近い傾向であること，また，ポリエチレンでは表面 加熱の傾向はみられるが，アクリルなどに比べて全体 的に吸収熱量が小さいことなどがわかる。これは図 6, 図 7 に示した分光透過率, 分光反射率加ら求めた 分光吸収係数(図 14) および図 5 に示した放射体の分 光放射輝度から定性的にわかるように，アクリル，テ 


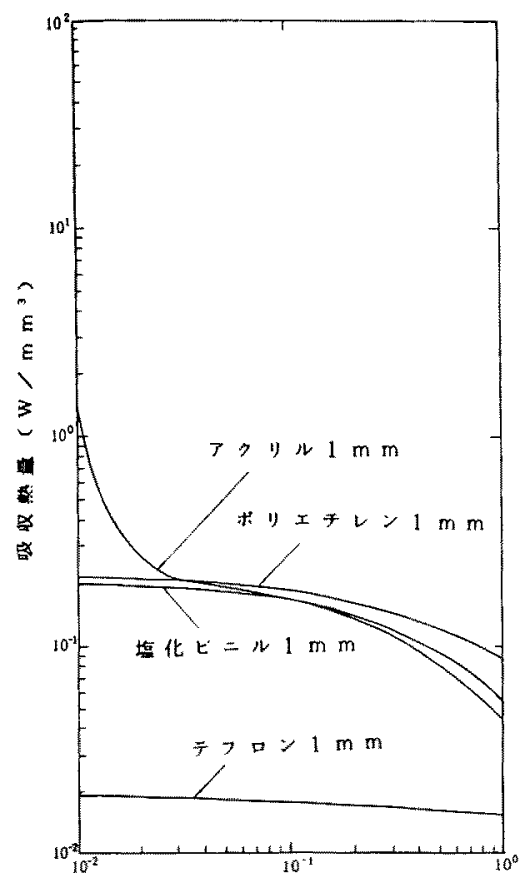

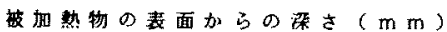

図 13 合成樹脂板内部の吸収熱量分不 (赤外線ランプ)

Fig. 13. Distribution of absorbed radiation heat flux by infrared lamp.

フロンおよび塩化ビニルでは遠赤外線ヒ一タ $\mathrm{A}, \mathrm{B}$ の主要放射波長領域（大きな放射熱流束をもつような 波長区間)に扔いて放射の吸収が非常に大きいこと, 逆にポリエチレンではこの区間での放射の吸収が小さ いことによる。

更に，ポリエチレンは他の合成樹脂板とは異なり遠 赤外線ヒ一タ Bで加熱するほうが遠赤外線ヒー夕 A の場合よりも全体的に吸収熱量が大きい。これはポり エチレンの吸收係数が遠赤外線ヒ一タBの分光放射 煇度のピーク波長付近で大きな值をもつことによる。

また，赤外線ランプ(図 13)では主要放射波長領域 において合成樹脂板の分光吸収倸数が非常に小さいた め，合成樹脂板内部で吸収される放射熱流束は遠赤外

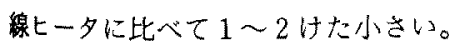

$\langle 4 \cdot 3\rangle$ 赤外線放射による加熱効果の予測 本解 析手法で法赤外線放射体の分光放射特性ならびに合成 棝脂板の分光透過率，分光反射率ならびに熱的物性值 を与えることによって，加熱開始後の昇温特性ならび に合成樹脂板内部の各場所での吸収熱量を計算するこ

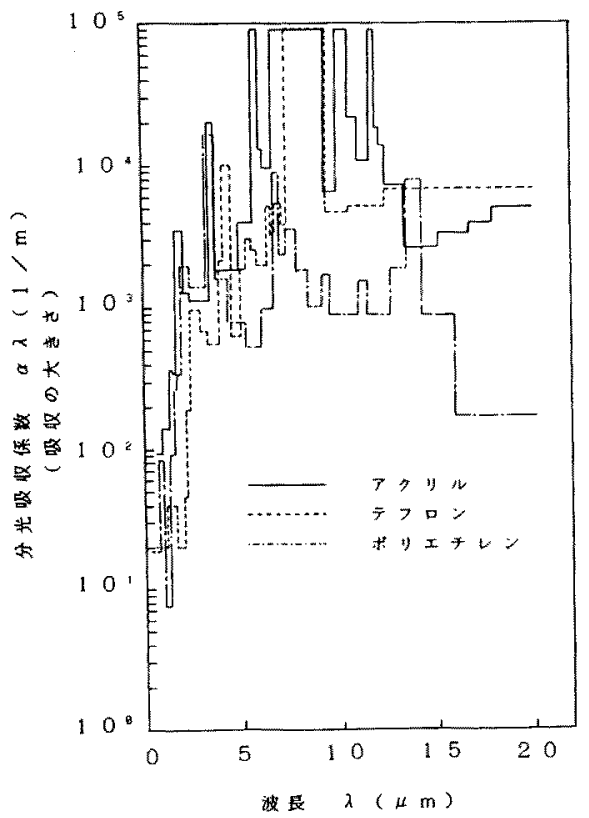

図 14 合成樹脂板 0 分光吸収係数

Fig. 14. Absorption coefficient of test pieces.

とができる。このため，本手法は赤外線加熱を有効に 行うための放射体の選択や加熱効果の定量的な予測に 有効である。

\section{5.まとめ}

溶融や蒸発などの物質移動を伴わない温度範囲で4 種の合成澍脂板を赤外線ランブおよび遠赤外線ヒー夕 を用いて加熱する実験を行うと共に，赤外線放射体の 分光放射率および合成樹脂板の分光透過率，分光反射 率を考慮した一次元熱移動モデルを用いて加熱過程を 理論的に検討した。その結果, 数值解析結果は実験結 果と比較的良い一致を示し, 本解析の妥当性が検証で きた。また，本手法は赤外線加熱を有効に行うための 放射体の選択や加熱効果の定量的な予測に有効で ある。

(平成元年 10 月 25 日受付, 同 2 年 4 月 18 日再受付)

\section{文献}

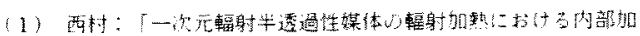
熟効果」, 化学工学論文集, 7, 245 (1981)

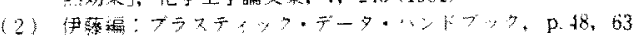

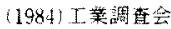

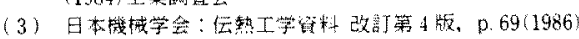




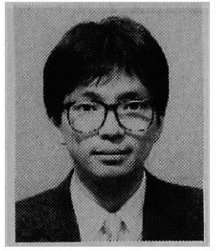

宮 永 俊 之 (正員)

昭和 39 年 3 月 3 日生。 61 年 3 月 九州大学工学部電子工学科卒業。6 63 年 3 月同大学院工学研究科電子工学 専攻修士課程修了。同年 4 月 (財) 電 力中央研究所入所, 現在に至る。主に, 赤外線加熱に 関する研究に従事。

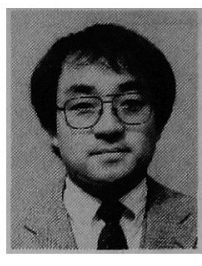

中 野幸夫 (正員)

昭和 32 年 3 月 4 日生。 54 年 3 月 名古屋大学工学部電気学科卒業。56 年 3 月同大学大学院工学研究科電気 工学専攻博士課程前期課程修了。同 年 4 月 (財) 電力中央研究所入所, 現在に至る。主に, 架空送電線の電気環境問題および赤外線加熱に関する 研究に従事。IEEE，赤外線技術研究会会員。 